\title{
Scientific Creativity Profile of Mathematics and Science Students
}

\author{
Andi Fadllan', Hartono ${ }^{2}$, Susilo ${ }^{3}$, Sigit Saptono ${ }^{4}$ \\ ${ }^{1234}$ Science Education, Graduate School, Universitas Negeri Semarang, Indonesia \\ ${ }^{1}$ Corresponding email: andi_fdl@walisongo.ac.id
}

\begin{abstract}
.
Creativity is an important ability for students to meet the challenges of the 21 st century. The aims of this study were to find out the profile of students' scientific creativity of Faculty of Science and Technology UIN Walisongo based on study programs and gender differences. It was a descriptive research with a quantitative approach. The data were obtained through Scientific Creativity Test (SCT) for 870 students. The data were analyzed descriptively by averaging the score of scientific creativity so that the level of scientific creativity of the respondents was obtained. Further, they were presented based on study programs and gender of the students as their scientific creativity profile. The mean score of students' scientific creativity was 43.25 with the standard deviation of 13.20 . Only $9.12 \%$ of students were in Creative and Very Creative level. These indicated that the majority of students had a low level of scientific creativity. Based on the study programs, Biology Education students had the highest mean score of 52.08 with the standard deviation of 16.77. Meanwhile, the lowest mean score was obtained by Physics Education program students, namely 37.29 with the standard deviation of 12.00. Based on gender differences, the mean score of the female students was better than the male students, namely 43.34 compared to 43.01 . These indicated that there was no significant difference in scientific creativity between male and female students.
\end{abstract}

Keywords: scientific creativity, study program, gender differences

\section{Introduction}

Teaching and learning with all its complexity is a place of inherently creative thinking. Creativity arises spontaneously through challenges and very specific situations in learning (Jackson, 2006). Universities play an important role in producing strong and creative experts in various fields of science that are able to answer the challenges of development. The college task is not only to convey the knowledge to the students to be memorized and preserved, but to form students into individuals and communities who are able to think critically, understand themselves and develop their potential so as to be competent in solving life problems and in future tasks.

Some creativity problems in college are: 1) being imaginative, producing new ideas, thinking out of the box, looking outside, seeing the world in different ways so as to explore and understand better, 2) being original and meaningful existence of novelty. For example, discovering and producing new things or adapting things that others have created; doing things never done before; doing things that have been done before but different; and important ideas: there are different levels and notions of meaning but their utility and value are thorough, 3) exploring, experimenting and taking risks, i.e. the process of seeking to discover something unknown, 4) cultivating, analyzing, and synthesizing data, situations, ideas or context to see the world differently and thinking critically to understand better, 5) communicating, often done through stories that help people see the world that has been made. Therefore, learning for creativity should be one of the main objectives of learning in college.

Creativity has been studied extensively by psychologists and researchers over the years, but studies of 'scientific creativity' and 'scientist creativity' are still rare (Pekmez et al, 2009). Creativity is an important aspect of scientific skill. A problem solving, hypothesis formulation, experimental planning and technical innovation require a distinctive creativity of science. A person can be creative in a particular field, but not in all fields. For example, a person may be creative in the Physics or Chemistry, but not in drawing (Liang, 2002). Essentially, scientific creativity is the ability to discover and solve new problems and the ability to formulate hypotheses, usually involving some prior knowledge, while artistic creativity may be able to provide some new life representations or feelings (Liang, 2002).

Based on the observation of the learning process in UIN Walisongo, scientific creativity has not developed well. More learning direct students to reproduce the knowledge they receive. Students just repeat the ideas that have been delivered by lecturers. One of the 
indicators is seen in the Introductory Physics lectures. In general, students who take this subject have been able to apply various formulas in solving mathematical problems and given physics. However, this ability is limited to simple and monotonous problems, not unique and complex issues. When the students are exposed to unique or complex physical problems, they are often incapable of thinking comprehensively and diverging (creatively).

Meanwhile, in some practicum subjects, students seem unable to experiment effectively and tend to be less creative. Handbooks or practice manuals are suspected to be the cause of the lack of students' scientific creativity. This is due to majority handbooks or practice manuals are in close-ended form. All the students' needs in carrying out the practicum are readily available so that they only follow the instructions without trying to do the lab with their own design. It may be different if the practice manual is made in an open-ended form where students are asked to design practicum activities with problems to be solved. This condition is certainly contrary to the purpose of learning in universities, namely preparing innovative, responsive, skilled, competitive, innovative, and creative students. Based on the problem, research has been done to find out the profile of students' scientific creativity of Faculty of Science and Technology UIN Walisongo based on study programs and gender differences.

\section{Methods}

This study was a descriptive research with a quantitative approach to describe the profile of students' scientific creativity of the Faculty of Science and Technology UIN Walisongo.

The population of this study were 870 students of Faculty of Science and Technology UIN Walisongo. Population were considered homogeneous because students were in a cluster of science.

The sample was determined with simple random sampling technique, with the number of research samples of 274 students. They were obtained by Slovin formula with 5\% significance level.

The following is a profile of students' scientific creativity reviewed based on study programs and gender differences. Data of
Students' scientific creativity data which were obtained by using Scientific Creativity Test (SCT) was adopted from Aktamis, et al (2005). It is a combination of Torrance's Test of Creative Thinking (TTCT) and Scientific Creativity Structure Model (SCSM) developed by $\mathrm{Hu} \&$ Adey (2002). Scientific Creativity Test consists of seven items that have been adapted to the characteristics of the research subjects.

The scientific creativity test was done according to the readiness of the research subject. The test was carried out by taking into account the time limit for each item. This restriction was intended to determine the extent to which creativity could be seen or appear within a short span of time. The overall time of the test was 35 minute. The data of the scientific creativity test were the summing score of three aspects of creativity, namely fluency, flexibility, and originality. It was then used to determine the level of students' scientific creativity. The level of scientific creativity consisted of Very Less Creative (VLC), Less Creative (LC), Creative Enough (CE), Creative (C), and Very Creative (VC). Data Level results are then presented in the form of tables and diagrams are made based on study programs and gender differences and presented descriptively.

\section{Result and Discussion}

Based on data of students' scientific creativity, the highest and lowest score, respectively were 95 and 15 so that the range of level scores was 16. The level of students' scientific creativity is shown in Table 1.

Table 1. Level of students' scientific creativity

\begin{tabular}{cl}
\hline \multicolumn{1}{c}{ Score } & \multicolumn{1}{c}{ Level } \\
\hline $15 \leq x \leq 31$ & $\begin{array}{l}\text { Very Less Creative } \\
\text { (VLC) }\end{array}$ \\
$31<\mathrm{x} \leq 47$ & Less Creative (LC) \\
$47<\mathrm{x} \leq 63$ & Creative Enough (CE) \\
$63<\mathrm{x} \leq 79$ & Creative (C) \\
$79<\mathrm{x} \leq 95$ & Very Creative (VC) \\
\hline
\end{tabular}

students' scientific creativity based on study programs is shown in Table 2. 
Table 2. Students' scientific creativity based on study programs

\begin{tabular}{lcccc}
\hline \multirow{2}{*}{\multicolumn{1}{c}{ Study programs }} & \multicolumn{3}{c}{ Score } & $\begin{array}{c}\text { Standard } \\
\text { deviation }\end{array}$ \\
\cline { 2 - 4 } & Mean & Highest & Lowest & 11.39 \\
Biology & 40.62 & 63 & 22 & 11.30 \\
Physics & 45.67 & 72 & 29 & 9.32 \\
Chemistry & 40.20 & 56 & 24 & 13.13 \\
Mathematics & 44.48 & 83 & 25 & 16.77 \\
Biology Education & 52.08 & 95 & 32 & 12.00 \\
Physics Education & 37.29 & 84 & 15 & 10.14 \\
Chemistry Education & 39.39 & 70 & 19 & 13.97 \\
Mathematics Education & 49.26 & 84 & 18 & 13.20 \\
\hline All samples & 43.25 & 95 & 15 & 150
\end{tabular}

Based on Table 2, the mean score of the sample was 43.25 with the highest and the lowest score were 95 and 15 respectively. The students of Biology Education study program got the highest mean score with 52.08. Meanwhile, the students Physics Education study program got the lowest mean score with 37.29 . This table also shows that the highest and lowest individual score was achieved by the students of Biology Education and Physics Education Study Program. The data of Level of students' scientific creativity are shown by Table 3 .

Table 3. Level of students' scientific creativity based on study programs

\begin{tabular}{lccccc}
\hline \multirow{2}{*}{ Study programs } & \multicolumn{5}{c}{ Number of students } \\
\cline { 2 - 6 } & VLC & LC & CE & C & VC \\
\hline Biology & 6 & 12 & 8 & 0 & 0 \\
Physics & 2 & 15 & 4 & 3 & 0 \\
Chemistry & 7 & 13 & 5 & 0 & 0 \\
Mathematics & 1 & 18 & 3 & 2 & 1 \\
Biology Education & 0 & 14 & 4 & 4 & 2 \\
Physics Education & 15 & 27 & 4 & 1 & 1 \\
Chemistry Education & 11 & 28 & 9 & 1 & 0 \\
Mathematics Education & 4 & 23 & 16 & 9 & 1 \\
\hline Total & 46 & 150 & 53 & 20 & 5 \\
\hline \multicolumn{7}{c}{ than 70\% of students were in Less Creative and } \\
Table 3, there were 20 students in & Very Less Creative. It indicated that the majority \\
5 students in Very Creative. It & of students had a low level of scientific \\
$12 \%$ of students were in Creative & creativity. Data of students' scientific creativity \\
ative from all sample. For more, & based on gender differences is shown by Table \\
of Biology and Chemistry study & 4.
\end{tabular}

Based on Table 3, there were 20 students in Creative and 5 students in Very Creative. It meant only $9.12 \%$ of students were in Creative and Very Creative from all sample. For more, the students of Biology and Chemistry study programs were none in Creative and Very Creative levels. This data also showed that more

Table 4. Students' scientific creativity based on gender differences

\begin{tabular}{lcccc}
\hline \multirow{2}{*}{ Genders } & \multicolumn{3}{c}{ Score } & $\begin{array}{c}\text { Standard } \\
\text { Deviation }\end{array}$ \\
\cline { 2 - 4 } & Mean & Highest & Lowest & 13.00 \\
Male & 43.01 & 83 & 18 & 13.29 \\
Female & 43.34 & 95 & 15 & 13.20 \\
\hline All samples & 43.25 & 95 & 15 & \\
\hline
\end{tabular}

Based on Table 4, the mean scores between male and female students differred slightly, by a margin of 0.33 . Female students were able to obtain the highest and lowest score, i.e. 95 and
15. The data of level of students' scientific creativity based on gender differences is showed in Table 5. 
Table 5. Level of students' scientific creativity based on gender differences

\begin{tabular}{lccccc}
\hline \multirow{2}{*}{ Genders } & \multicolumn{5}{c}{ Number of students } \\
\cline { 2 - 6 } & VLC & LC & CE & C & VC \\
\hline Male & 12 & 43 & 12 & 6 & 1 \\
Female & 34 & 107 & 41 & 14 & 4 \\
\hline Total & 46 & 150 & 53 & 20 & 5 \\
\hline
\end{tabular}

Based on Table 5, for female students, there were 14 students in Creative and four students in Very Creative. It meant only $9.00 \%$ female students were included in creative. On the other hand, for male students, there were six students in Creative and one students in Very Creative or 9.45\% students were included in creative. In the level of Very Less Creative, there were $16.22 \%$ male students and $17.00 \%$ female. Additionally, in the level of Less Creative, there were $58.11 \%$ male students and $53.50 \%$ female.

According to the results of the students' scientific creativity test, it appeared that the students of Biology Education had the highest mean score, that was 52.08, and highest standard deviation, which was 16.77. It meant the students' scientific creativity spread from the lowest to the highest of scores.

The lowest mean score was obtained by Physics Education students, which was 37.29 with the standard deviation of 12.00. The number of students in Very Less Creative level were as many as 15 of 48 students or $31.25 \%$. This percentage was the largest percentage if compared with other study programs. For example, in Biology study program $(23.08 \%)$, Physics (8.33\%), Mathematics (4.00\%), Chemistry Education (22.45\%), and Mathematics Education (7.55\%).

Meanwhile, when compared to the overall mean score of the sample (43.25), there were four study programs that had an mean score below the overall mean of the sample, i.e. Biology $\left(\bar{x}_{1}=40,62\right)$, Chemistry $\left(\bar{x}_{3}=40.20\right)$, Physics Education $\left(\bar{x}_{6}=37.29\right)$, dan Chemistry Education $\left(\bar{x}_{7}=39.39\right)$.

Based on the three aspects of ability in creativity, i.e fluency, flexibility and originality, the mean score of each study programs is shown in Table 6.

Table 6. Students' scientific creativity scores according to aspects of creativity

\begin{tabular}{lccc}
\hline \multirow{2}{*}{\multicolumn{1}{c}{ Study programs }} & \multicolumn{3}{c}{ Mean score } \\
\cline { 2 - 4 } & Fluency & Flexibility & Originality \\
\hline Biology & 3.6 & 2.6 & 1.1 \\
Physics & 4.1 & 3.0 & 1.2 \\
Chemistry & 3.6 & 2.5 & 1.1 \\
Mathematics & 3.1 & 3.2 & 1.3 \\
Biology Education & 4.1 & 3.6 & 1.5 \\
Physics Education & 3.3 & 2.5 & 0.9 \\
Chemistry Education & 3.4 & 2.6 & 1.1 \\
Mathematics Education & 4.2 & 3.3 & 1.3 \\
\hline Average score & 3.73 & 2.91 & 1.19 \\
\hline
\end{tabular}

Based on data from Table 6, Mathematics Education students had better fluency than others. The mean fluency score indicated that the student had the ability to generate many ideas quickly. The fluency score was derived from the research subject's answer by presenting as many answers as possible, regardless of whether the answer was logical or not, true or false, and relevant or not to the question. In general, research subjects who managed to obtain high scores on fluency aspects were those who were accustomed to thinking fast in very urgent conditions.

Originality scores were developed from the frequency tabulation of all the research subjects' responses. The frequency and percentage of each answer were then calculated. This score showed that the research subjects were able to produce ideas in original ways. Creative people have the ability to create ideas or thoughts in new, imaginative, original and different forms from old and commonly used problem solving 
ideas. Creative people can reach beyond the thinking of the average person, think in a unique way beyond commonly used ways, question old ways and try to think of new ways or often question why a thing should be done in a way and not in other ways, and provide colors that are firm and different from the original state (in drawing).

Based on table 6 , the mean score of the fluency was better than the flexibility, and the flexibility was better than the originality. These further strengthened that the fluency was the most basic or lowest ability in scientific creativity. Then originality was the highest aspect of ability in creativity. In other words, someone with good fluency does not necessarily have flexibility and good originality. However, someone with good originality usually has good fluency and flexibility.

The mean score of female students' was slightly better than male students and the highest score of female students was also better than male students. However, both samples were homogeneous. Based on the mean difference test, obtained $\mathrm{t}$-count $=0.18$ and $\mathrm{t}$-table $=1.97$ so the two samples did not differ significantly.

The results of this research are accordance with other researches. Cramond, et al (2005) have found that there is a relationship between gender differences with the level of creativity both in the form of quantity and quality. The results of their analysis of research journals from 1958-1998 found a difference in both of fluency, flexibility, originality, and elaboration. Women tend to be higher on the fluency, originality, and elaboration, whereas in the male flexibility tends to be higher although the difference is not too high.

Other research results showing the advantages of the female over male were also found by Handayani and Novianto (2004) in the Javanese. With qualitative methods, they found that Javanese female and male are educated differently. Female are more educated to deal with practical issues in the household, such as cooking, sweeping floors, cleaning kitchen utensils, washing clothes, drying and ironing making clothes. These activities are done every day constantly with different problems; for example, girls are taught how to cook vegetables with various spices and ways, clean up various types of stains on clothes, ironing various types and models of clothing, or clean and arranging kitchen utensils made of wood, aluminum or stainless steel. This condition causes female to be better equipped to deal with and solve various possible problems encountered with various alternative solutions. Conversely, male are more accustomed to out of home orientation, work with imagination, and tend to be abstract, such as follow up work to clean up sewers or repair damaged roads, play in the field with friends, ride biking to various places, making various types of wooden toys, plywood or banana leaf bark so that when they face practical problems, they become less tactful and dexterous than female. They do not know what to do. Handayani and Novianto (2004) also suggest that the parenting pattern that specializes in Javanese male tends to damage his mental condition, namely the existence of indulgence and dependence on a mother and sister in his home environment. This even continues until adulthood, that is, the Javanese male will return to behave like a child to his wife. They always ask to be served by the wife in various ways, such as taking food or drink, cleaning clothes, cleaning up household items, to prepare work equipment (clothes, pants, shoes, ties, and bags).

Comparative research in terms of male and female creativity has also been done by Munandar (1977) in high school students in Indonesia. $\mathrm{He}$ found that female creativity tended to be higher than that of men with a ratio of $58 \%$ to $42 \%$. Similar results found Aziz (2006), based on the results of his research on 82 children who have a high level of creativity was more obtained by female than male with a ratio of $35(53 \%)$ versus $31(47 \%)$.

The differences between the male and female in various aspects of psychology, especially in creativity can be understood from different points of view. Brizendine (2006, in Aziz, 2006), a neuropsychiatrist and clinical director specializing in the functioning of the female brain, explain that there are differences in male and female brain structures, which result in differences in ways of thinking, how to look at things, how to communicate, and so forth. Carlson's research (Purwati, 1993) found that male tend to be higher in social orientation while female are more personally oriented.

Meanwhile, Sperry's findings as revealed by Wycoff (1991) describes the existence of two types of brain in every human right brain is more rational and left brain is more irrational. Pasiak (in Aziz, 2006) explains that the way the left hemisphere is more serial, sequential, and very concerned with the things that are concrete and realistic, while the right brain is more 
parallel, not patterned, and emphasizing things that are abstract and intuitive. Furthermore, Wycoff (1991) states that creativity arises from the interaction between the two hemispheres and the left brain, although many experts say that the right brain is more associated with creativity because of its abstract and intuitive workings. The ability to think and write creatively is more of a more personal and intuitive activity, so it can be understood if women have higher abilities than men in both fields, although of course these findings still need more empirical testing deep and thorough.

The results of the analysis that states the existence of this difference is interesting to be observed further because no stronger reason has been found whether women are higher in creativity because of the natural aspect that is biologically structurally supportive to the high creativity or more due to the constructed aspect of society provide different treatment between men and women. Pinker (2009) said that assessing creativity based on gender differences is one of the most controversial and interesting research lines. However, it is too naive to say that one gender is more creative than the other or there is absolutely no difference between the two genders.

\section{Conclusion}

Based on data analysis and discussion that has been done, it can be concluded that the mean score of science creativity test result of Science and Technology Faculty students of UIN Walisongo was 43.25 with standard deviation of 13.20. Percentage of students who belonged to Creative and Very Creative level was $9.12 \%$ from all sample of research. Students of Biology and Chemistry study program are not in Creative and Very Creative levels. This study also concluded that the mean score of research subjects in all three aspects of scientific creativity ability were 3.73 (fluency), 2.91 (flexibility), and 1.19 (originality). The aspect of fluency ability is the most basic aspect of ability possessed by a creative person. While the aspect of originality is a higher aspect of ability in creativity.

\section{References}

Aktamıs, H. et al. (2005). Developing Scientific Creativity Test (University of Dokuz Eylul) http://www.clab.edc.uoc.gr/2nd/pdf/58.pd f.

Aziz, R. (2006). Studi tentang kreativitas pada siswa sekolah menengah pertama di kota malang. Psikoislamika. 3, 239-254

Brizendine, L. (2006). Female Brain. New York: Morgan Road Books.

Cramond, B. (2005). A report on the 40-year follow-up of the Torrence tests of creative thinking: Alive and Well in the new millennium, Gifted Child Quarterly. 49, 283-291.

Handayani, C. S. and Novianto. A. (2004) Kuasa Wanita Jawa. Yogyakarta: LKiS

Hu, W. and Adey, P.A. (2002). Scientific creativity test for secondary school students Int. J. Sci. Educ. 24, 389-403.

Jackson, N. (2006). Creativity in higher education: what's the problem? The Magazine of the Staff and Educational Development Association Ltd (SEDA). 7, 1-24

Liang, J. (2002). Exploring scientifc creativity of eleventh grade students in Taiwan. Unpublished Doctoral Dissertation (The University of Texas at Austin)

Munandar. (1977). Creativity and Education. Jakarta: Dirjen Pendidikan Tinggi, Departemen Pendidikan dan Kebudayaan.

Pekmez, E.S. et al. (2009). Exploring scientific creativity of $7^{\text {th }}$ grade students J. Qafqaz Univ. 26, 204-214

Purwati. (1993). Hubungan antara pola asuh orangtua dengan penyesuaian diri remaja. Thesis. Yogyakarta: Graduate School of Psichology Department of Universitas Gadjah Mada.

Pinker, S. (2009). The sexual paradox: Men, women and the real gender gap. NewYork: Scribner.

Wycoff, J. (1991).Mindmapping: Your Personal Guide to Exploring Creativity and Problem Solving. New York: Berkley Book. 